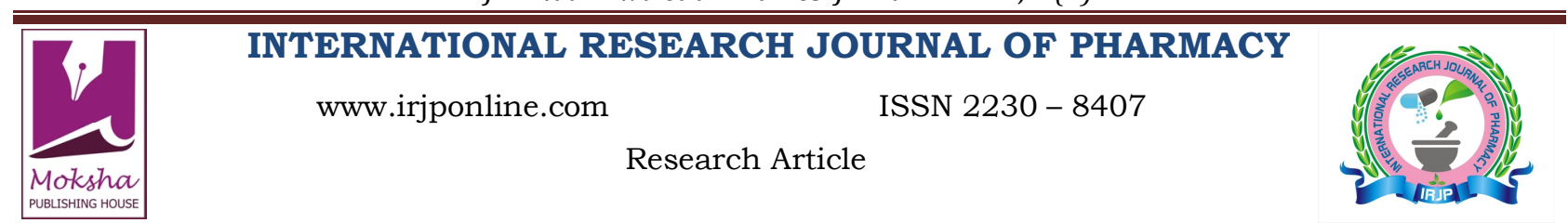

\title{
PHYTOCHEMICAL SCREENING AND IN VITRO ANTIMICROBIAL ANALYSIS OF THE ETHANOL STEM BARK EXTRACT OF JATROPHA CURCAS LINN. (EUPHORBIACEAE)
}

\author{
J. H. Wakirwa ${ }^{1}$, P. Ibrahim ${ }^{1}$, and S. J. Madu ${ }^{2}$ \\ ${ }^{1}$ Department of Pharmacognosy, University of Maiduguri, P.M.B. 1069, Maiduguri, Borno State, Nigeria \\ ${ }^{2}$ Department of Pharmaceutics and Pharmaceutical Microbiology, University of Maiduguri, P.M.B. 1069, Maiduguri, Borno \\ State, Nigeria \\ Email: joecomf2001@yahoo.com
}

Article Received on: 10/01/13 Revised on: 11/02/13 Approved for publication: 11/03/13

DOI: $10.7897 / 2230-8407.04317$

IRJP is an official publication of Moksha Publishing House. Website: www.mokshaph.com

(C) All rights reserved.

\section{ABSTRACT}

This study covers the phytochemical and antimicrobial analysis of the ethanol stem bark extract of Jatropha curcas Linn. The results obtained indicates the presence of some secondary metabolites; saponins, tannins, cardiac glycosides, carbohydrates, reducing sugars, flavonoids and terpenoids. The extract also exhibited antimicrobial activities which were dose-dependent with zones of inhibition ranging from 10-15mm for Staphylococcus aureus, 11-17mm for E. coli, 10-18mm for Klebsiella pneumoniae, and 14-26mm for Candida albicans. The MIC of the extract on the clinical isolates (Staphylococcus aureus, Escherichia coli, and Klebsiella pneumonia) was $25 \mathrm{mg} / \mathrm{ml}, 25 \mathrm{mg} / \mathrm{ml}$ and $50 \mathrm{mg} / \mathrm{ml}$, respectively. While the MBC of Staphylococcus aureus, Escherichia coli and Klebsiella pneumoniae was $50 \mathrm{mg} / \mathrm{ml}, 50 \mathrm{mg} / \mathrm{ml}$ and $100 \mathrm{mg} / \mathrm{ml}$, respectively. The results obtained indicate that ethanol stem bark extract of Jatropha curcas has antibacterial and antifungal activity which can be attributed to the presence of some of the essential secondary metabolites.

Key words: Ethanol Stem bark extract, Phytochemistry, Antimicrobial analysis, Jatropha curcas.

\section{INTRODUCTION}

Traditional medicine using plant extracts continue to provide health coverage for over $80 \%$ of the world's population, especially in the developing world ${ }^{1}$. It was reported that $60 \%$ - $85 \%$ of the population in every country of the developing world has to rely on traditional medicine or indigenous forms of medicine ${ }^{2}$.

Jatropha curcas (Euphorbiaceae) is believed to be a native of South America and Africa but later spread to other continents of the world ${ }^{3}$. It is used in traditional folklore medicine to cure various ailments in Africa, Asia and Latin America ${ }^{4}$. It is a wild growing hardy plant well adapted to acid and moisture demand and can come up in stony, gravelly and even calcareous soils. Jatropha curcas can be grown in habitat of tropical/subtropical areas with a suitable rainfall of 200-1500 mm/year ${ }^{5}$.

Anti-microbial agents are substances that kill microorganisms or inhibit their growth. They are widely employed to cure bacterial diseases. An antimicrobial agent that reversibly inhibits the growth of bacteria is called bacteriostatic whereas those with irreversible lethal action on bacteria are known as bactericidal ${ }^{6}$. The development of resistance in human pathogens against antibiotics commonly used necessitates research for new antimicrobial substances from other sources including plants ${ }^{7}$. Therefore, this study is aimed at evaluating the antibacterial and antifungal activities of ethanol stem bark extract of Jatropha curcas and investigate its phytochemical components.

\section{MATERIALS AND METHODS}

Source of Plant Material, Collection and Identification

The fresh stem bark of Jatropha curcas collected February, 2012 from Kaltungo Local Government Area of Gombe State was identified by Professor S. S. Sanusi a Taxonomist in the Department of Botany, University of Maiduguri, and a voucher specimen number PCG0026 was assigned and deposited in Department of Pharmacognosy Herbarium, University of Maiduguri.

\section{Preparation of the Stem Bark Extract}

The Fresh stem bark of Jatropha curcas collected was air dried to a constant weight, pulverised in a mill (TYPE YC100L-4, China) and stored in an air tight container for further use. A $600 \mathrm{~g}$ weight of the pulverised stem bark of Jatropha curcas was de-fatted using petroleum ether for 24 hours; the marc was dried and soaked in $1.5 \mathrm{~L}$ of ethanol for 24hours at room temperature with occasional mechanical shaking. The mixture was filtered and the marc was reextracted with $150 \mathrm{ml}$ of ethanol. The filtrate obtained was concentrated using Rotary evaporator (R201D, U.S.A.) and the extract subsequently air dried. The weight of the ethanol extract obtained was $33.0 \mathrm{~g}$ (5.5\% Yield).

\section{Source of the Microorganisms}

Clinical isolates of the tests organisms (staphylococcus aureus, Escherichia coli, Klebsiella pneumoniae and Candida albicans) were obtained from the Department of Microbiology, University of Maiduguri Teaching Hospital (UMTH).

\section{Phytochemical analyses of the stem bark extract of Jatropha curcas Linn.}

The ethanol stem bark extract of Jatropha curcas was subjected to preliminary phytochemical analysis for secondary metabolites; saponins, tannins, cardiac glycosides, alkaloids, carbohydrate, reducing sugar, flavonoids, anthraquinones and terpenoids in accordance with Evans ${ }^{8}$ and Sofowora 9 .

Antimicrobial analyses of the stem bark extract of Jatropha curcas Linn.

\section{Sterilization of the equipments and disinfection}

All work surfaces were mopped with moist hand towel and was disinfected with Dettol ${ }^{\circledR}$ (chlorhexidine and cetrimmide) so as to reduce microbial load on working surface. 
Dry heat sterilization

A hot air oven was used to sterilize the conical flasks, forceps, wire loop, pipettes, and beakers at $160^{\circ} \mathrm{C}$ for 2 hours.

\section{Moist heat sterilization}

Moisture insensitive equipments and materials used for microbiological processes were sterilized in an autoclave (YX-280B, China) at $121^{\circ} \mathrm{C}$ for 15 minutes.

\section{Preparation of Media}

The medium (Nutrient Agar and Nutrient broth) were prepared according to manufacturer's instruction.

\section{Zone of inhibition- well diffusion method}

One gram weight of the extract was dissolved in $10 \mathrm{ml}$ sterile distilled water in order to obtain a stock concentration of $100 \mathrm{mg} / \mathrm{ml}$. The stock was then serially diluted to the following concentrations; $50 \mathrm{mg} / \mathrm{ml}, 25 \mathrm{mg} / \mathrm{ml}, 12.5 \mathrm{mg} / \mathrm{ml}$ and $6.25 \mathrm{mg} / \mathrm{ml}$.

A standard cork borer of $8 \mathrm{~mm}$ in diameter was used to bore three wells for each inoculated plate and the agar removed from the well. $0.1 \mathrm{ml}$ of the test extract was then introduced into the well created at the center of each of the plate. The bacteria plates were incubated at $37^{\circ} \mathrm{C}$ for 24 hours and observed for the zone of inhibition of growth while the fungal plates were incubated at $30^{\circ} \mathrm{C}$ for $1-7$ days. The zones were measured with a transparent ruler and result recorded in millimeters. The screening was done in triplicates and the mean and standard deviation determined.

\section{Determination of the minimum inhibitory concentration (MIC)}

The MIC of the ethanol stem bark extract of Jatropha curcas was carried out using broth dilution method as described by Ibekwe et al., ${ }^{10}$.

A set of 9 Bijou bottles were arranged serially and filled with $5 \mathrm{ml}$ of nutrient broth. The first bottle contained the double strength nutrient broth. A $1.0 \mathrm{~g}$ ethanol stem bark extract of Jatropha curcas was dissolved in $5 \mathrm{ml}$ distilled water and added to the first bottle (i.e. the double strength nutrient broth), it was mixed thoroughly and $5 \mathrm{ml}$ was subsequently withdrawn and poured into the second bottle. This procedure was continued up to the $7^{\text {th }}$ bottle where $5 \mathrm{ml}$ was withdrawn and discarded. The bottle number 8 contain only nutrient broth i.e. the negative control to examine the sterility of the media and bottle number 9 contains the organism (positive control). A loop full of the diluted overnight culture of a sensitive gram negative (Escherichia coli and klebsiella pneumoniae) and gram positive organism (staphylococcus aureus) were inoculated. All the bottles were incubated at $37^{\circ} \mathrm{C}$ for 24 hours in an electric incubator (DHG-9023A, China).

The bottles were observed for turbidity of growth after 24 hours. The lowest concentration which showed no turbidity in the bottle was recorded as the MIC.

\section{Determination of the minimum bactericidal concentration (MBC)}

The broth dilution method as described by Ibukun ${ }^{11}$ was adopted. All the test bottles which showed no turbidity in the MIC assay were sub-cultured into a nutrient agar plate and incubated at $35^{\circ} \mathrm{C}$ for 24 hours and observed for colony growth.

The MBC was the plate with the lowest concentration of extract without colony growth.

\section{Determination of activity index}

The activity index of the ethanol stem bark extract of Jatropha curcas was calculated according to Arya et al., ${ }^{12}$.

Activity index (A.I.) = Mean of zone of inhibition of the extract

Zone of inhibition obtained for standard antibiotic drug

\section{Statistical Analysis}

Paired-Sample T-Test was used in the analysis in order to determine the level of significance of the various bacterial zones of inhibition observed. P-value $<0.05$ was considered significant.

Table 1: Qualitative phytochemistry of ethanol stem bark extract of Jatropha curcas Linn.

\begin{tabular}{|c|c|}
\hline Secondary metabolites & Results \\
\hline Saponins & + \\
\hline Tannins & + \\
\hline Cardiac glycosides & + \\
\hline Alkaloids & - \\
\hline Carbohydrates & + \\
\hline Reducing sugars & + \\
\hline Flavonoids & + \\
\hline Anthraquinones & + \\
\hline Terpenoids &
\end{tabular}

$+=$ present, $-=$ absent

Table 2: Antimicrobial analyses of ethanol stem bark extract of Jatropha curcas Linn. Showing the zones of inhibition (mm) (n=3)

\begin{tabular}{|c|c|c|c|c|c|c|c|}
\hline \multirow[t]{2}{*}{ Organisms } & \multicolumn{7}{|c|}{ Concentration $(\mathrm{mg} / \mathrm{ml})$} \\
\hline & Negative control & Positive control & 100 & 50 & 25 & 12.5 & 6.25 \\
\hline S. aureus & - & $18.00 \pm 2.00$ & $15.00 \pm 1.00$ & $13.67 \pm 0.58 *$ & $12.67 \pm 0.58$ & $12.00 \pm 2.00$ & $10.00 \pm 2.65$ \\
\hline E. coli & - & $54.33 \pm 2.08$ & $17.33 \pm 0.58^{*}$ & $14.67 \pm 0.58^{*}$ & $13.33 \pm 0.58^{*}$ & $13.00 \pm 1.00^{*}$ & $11.00 \pm 1.00 *$ \\
\hline K. pneumoniae & - & $30.67 \pm 3.21$ & $18.33 \pm 0.58^{*}$ & $14.33 \pm 0.58 *$ & $12.33 \pm 0.58^{*}$ & $10.00 \pm 1.00^{*}$ & 0.00 \\
\hline C. albicans & - & $36.67 \pm 1.53$ & $26.67 \pm 2.08^{*}$ & $20.33 \pm 1.53 *$ & $14.67 \pm 0.58 *$ & - & - \\
\hline
\end{tabular}

*indicates a significant difference with positive control at p-value $<0.05$. (T- Test) Negative control $=$ Distilled water. Positive control $=$ Ciprofloxacin and Ketoconazole for bacterial and fungal isolates respectively. S. aureus = staphylococcus aureus, E. coli $=$ Escherichia coli,

K. pneumoniae $=$ Klebsiella pneumoniae, C. albicans $=$ Candida albicans. 
Table 3: MIC, MBC and Activity index (A.I.) of ethanol extract of Jatropha curcas stem bark

\begin{tabular}{|c|c|c|c|}
\hline Organism & MIC (mg/ml) & MBC (mg/ml) & Activity index (A.I.) \\
\hline S. aureus & 25 & 50 & 0.76 \\
\hline E. coli & 25 & 50 & 0.27 \\
\hline K. pneumoniae & 50 & 100 & 0.47 \\
\hline C. albicans & Not tested & No effect & 0.55 \\
\hline
\end{tabular}

$\mathrm{MIC}=$ Minimum inhibitory concentration. $\mathrm{MBC}=$ Minimum bactericidal concentration. $S$. aureus $=$ staphylococcus aureus, E. coli $=$ Escherichia coli K. pneumoniae $=$ Klebsiella pneumoniae, C. albicans $=$ Candida albicans.

\section{RESULTS \\ Qualitative phytochemistry of ethanol stem bark extract of Jatropha curcas Linn.}

Details of the various phytochemical constituents present or absent in the ethanol stem bark extract of Jatropha curcas is shown in Table 1. The extract showed the presence of saponins, tannins, and cardiac glycosides, carbohydrates, reducing sugars, flavonoids and terpenoids.

\section{Antimicrobial analyses of ethanol stem bark extract of} Jatropha curcas Linn.

Table 2 shows a dose dependent effect of the extract on bacterial growth with a better activity against Klebsiella pneumoniae at $100 \mathrm{mg} / \mathrm{ml}$ concentration but significantly less than positive control (ciprofloxacin), no inhibition of growth was observed at $6.25 \mathrm{mg} / \mathrm{ml}$. It is however important to note that there was no significant difference $(\mathrm{P}$-value $<0.05)$ in the zone of inhibition of the extract $(100 \mathrm{mg} / \mathrm{ml})$ against staphylococcus aureus compared to the positive control (ciprofloxacin). Growth inhibition against Escherichia coli was also dose dependent and significantly less than positive control at all the concentrations used.

The inhibition of growth Candida albicans was also dose dependent with significantly lower zone compared to positive control (Ketoconazole) as shown in Table 2.

\section{MIC, MBC and Activity index (A.I.) of ethanol extract of} Jatropha curcas stem bark

The minimum inhibitory concentration of the ethanol extract of Jatropha curcas stem bark was 25, 25 and $50 \mathrm{mg} / \mathrm{ml}$ for staphylococcus aureus, Escherichia coli, and Klebsiella pneumonia respectively while that of Candida albicans was not tested. In like manner, the minimum bactericidal concentration was 50,50 and $100 \mathrm{mg} / \mathrm{ml}$ for staphylococcus aureus, Escherichia coli, and Klebsiella pneumonia respectively while that of Candida albicans was not tested. Activity index obtained was $0.76,0.27,0.47$ and 0.55 for staphylococcus aureus, Escherichia coli, Klebsiella pneumonia and Candida albicans respectively (Table 3).

\section{DISCUSSION}

The phytochemical analysis of the ethanol stem bark extract of Jatropha curcas showed the presence of some secondary metabolites as shown in Table 1. Alkaloids and anthraquinones were found to be absent. This result contradicts the findings of Igbinosa ${ }^{13}$. However, the difference in geographical location of the plant collection could justify such difference. It is important to note also that contrary to the findings of Obasi et al., ${ }^{14}$ who studied the methanol stem bark extract of Jatropha curcas, the ethanol stem bark extract of Jatropha curcas contains tannins and flavonoids which according to James et al., ${ }^{15}$ reported that tannins and flavonoids have biological activities that are of benefit in the prevention and management of many ailments. Erah et al., ${ }^{16}$ had reported earlier that antimicrobial activities are associated with the presence of tannins and flavonoids.
The presence of other preformed compounds like saponins which is in concordance with the findings of Obasi et al., ${ }^{14}$ also justifies the antifungal property of the extract ${ }^{17}$. Therefore the presence of this essential secondary metabolites in the extract used explains the broad spectrum antimicrobial activity in this study.

The observations that emanated in the present study as shown in Table 2 indicated that the extract used demonstrated a dose dependent activity against the bacteria (both Gram positive and Gram negative) and fungal isolates used. There was no activity with the negative control (distilled water). The positive control (Ciprofloxacin $50 \mathrm{mg} / \mathrm{ml}$ and Ketoconazole $50 \mathrm{mg} / \mathrm{ml}$ for bacterial and fungal isolates respectively) showed significant higher zone of inhibition. Compared to the extract studied at various concentrations employed (Pvalue $<0.05)$. The difference may be attributed to the fact that positive controls employed are pure compounds compared with the doses of the crude ethanol stem bark extract of extract of Jatropha curcas used ${ }^{7}$. Also, ElMahmood and Amey ${ }^{18}$ reported that crude extracts having a mixture of plants constituents interfered with antimicrobial activity via degradation and decomposition especially on long term storage. The results obtained also demonstrated that the extract used has a better activity against $E$. coli compared with both $S$. aureus and $K$. pneumoniae except at the highest concentration of the extract $(100 \mathrm{mg} / \mathrm{ml})$ where activity against $K$. pneumoniae is better than $E$. coli. This result shows that the ethanol stem bark extract of Jatropha curcas has a better activity against Gram negative compared to Gram positive bacteria. These findings are supported by the report of Gupta et al., ${ }^{19}$. The activity of the extract against $C$. albicans was only observed at higher concentrations $(25,50$ and $100 \mathrm{mg} / \mathrm{ml}$ ) which was dose dependent. This could be an indication that the extract has better antifungal activity at higher concentration. This is also in line with the findings of Igbonosa ${ }^{13}$.

High MIC value is an indication of low activity while low MIC value is an indication of high activity. $\mathrm{MBC}$ is the lowest concentration of antibiotic required to kill a particular bacterium ${ }^{20}$. From the results shown in Table 3, the extract used has a better activity against $S$. aureus and E. coli compared to K. pneumoniae.

\section{CONCLUSION}

Conclusively, based on the findings of this study, the ethanol stem bark extract of Jatropha curcas exhibited activities against bacterial and fungal growth which can be attributed to the presence of some essential secondary metabolites present. Thus, the result of this study provides support for the traditional use of Jatropha curcas as an antibacterial and antifungal agent.

\section{REFERENCES}

1. WHO. Traditional Medicine: Growing Needs and Potentials. WHO Policy Perspectives on Medicines. World Health Organization, Geneva 2002; pp. 1-6.

2. Erinosho OA, Ayonrinde A. Traditional Medicine in Nigeria. Federal Ministry of health, Lagos 1995. 
3. Gubitz GM, Mittelbach M, Trabi M, Exploitation of the tropical oil seed plant Jatropha curcas L., Bio-resource Technology 1999; pp. 67, 73-82.

4. Burkill HM. The useful plants of West Tropical Africa (Families EJ), Royal Botanical Gardens Kew 1994, pp. 90-94.

5. Oliver-Bever B. Medicinal Plants in Tropical West Africa, Cambridge University Press, London: 1986. http://dx.doi.org/10.1017/ CBO9780511753114

6. Rajesh B, Rattan LI. Essentials of Medical Microbiology. 4th Edn. Jaypee Brothers Medical Publishers (P) Ltd. New Delhi, India 2008. 500 pp.

7. Timothy SY, Lamu FW, Rhoda AS, Adati RG, Maspalma, ID and Askira M. Acute toxicity, phytochemical and antibacterial activity of aqueous and ethanolic leaf extracts of Cassia alata Linn. International Research Journal of Pharmacy 2012; 3(6):73-76.

8. Evans WC. General Methods associated with the phytochemical investigation of Herbal Products: Trease and Evans text book of Pharmacognosy. 15 edn. Elsevier, India 2002. pp 137-138.

9. Sofowora A. Medicinal plants and Traditional Medicine in Africa. 3rd edn. Spectrum books limited: Ibadan, Nigeria, 2008. pp 140-152.

10. Ibekwe VI, Nnanyere NF, Akujobi CO. Studies on Antibacterial Activity and Phytochemical qualities of Extracts of Orange peels. Int. J. Environ. Health and Human Dev., 2001; 2(1):41-46.

11. Atansuyi K, Ibukun EO, Ogunmoyole T. Antioxidant properties of free and bound phenolic extract of the leaves of Jatropha tanjorensis in vitro. Journal of Medicinal Plants Research 2012; Vol. 6(31), pp. 4667-4674, 15.

12. Arya V, Yadav S, Kumar S, Yadav JP. Antimicrobial activity of Cassia occidentalis L (Leaf) against various Human Pathogenic Microbes. Life Sciences and Medicine Research 2010: LSMR-9: 1-11.
13. Igbinosa OO, Igbinosa EO, Aiyegoro OA. Antimicrobial activity and phytochemical screening of stem bark extracts from Jatropha curcas (Linn). African Journal of Pharmacy and Pharmacology 2009; Vol. 3(2). pp. 058-062.

14. Obasi NL, Ejikeme M P, Egbuonu CAC. Antimicrobial and phytochemical activity of methanolic extract and its fractions of Jatropha curcas Linn. (Euphorbiaceae) stem bark. African Journal of Pure and Applied Chemistry 2011; Vol. 5(5), pp. 92-96.

15. James DB, Abu EA, Wurochekk AU, Orji GN. Phytochemical and antimicrobial investigations of aqueous and methanolic extracts of Ximenia Americana. J. Med. Sci 2007; 7(2): 284-288. http://dx.doi.org /10.3923/jms.2007.284.288

16. Erah PO, Osuide GE, Omogbai EKI. Hypoglycaemic effect of the extract solenstemon monostachys (P. Beauv) leaves. J. West Afr. Pharm 1996; 10: 21-27.

17. Aboaba OO, Efuwape BM. Antibacterial properties of some Nigerian species. Bio. Res. Comm 2001. 13: 183-188.

18. El-Mahmoud AM, Doughari JH. Phytochemistry and activity of Cassia alata. African Journal of Pharmacy and Pharmacology 2008; 2(7): 124129.

19. Gupta S, Srivastava M, Mishra GP, Naik PK, Chauhan RS, Tiwari S K et al. Analogy of ISSR and RAPD markers for comparative analysis of genetic diversity among different Jatropha curcas genotypes 2008; Afr. J. Biotechnol. 7, 4230-4243.

20. Mimm and Plafair. Medical Microbiology. Mosby Europe 1933. 35:31.

\section{Cite this article as:}

J. H. Wakirwa, P. Ibrahim, S. J. Madu. Phytochemical screening and in vitro antimicrobial analysis of the ethanol stem bark extract of Jatropha curcas Linn. (Euphorbiaceae). Int. Res. J. Pharm. 2013; 4(3):97-100 